\title{
Sciendo
}

\section{Public Health Policies in the Akyem Abuakwa of Ghana (1850-1957)}

\author{
SAMUEL ADU GYAMFI* - PHINEHAS ASIAMAH ** - \\ BENJAMIN DOMPREH DARKWA*** LUCKY TOMDI****
}

Department of History and Political Studies,

Kwame Nkrumah University of Science and Technology, Kumasi, Ghana

*mcgyamfi@yahoo.com

**phinehasasiamah1@gmail.com

**darkwa687@gmail.com

**** Department of History,

University of New Brunswick, Canada

tomdilucky14@gmail.com

\begin{abstract}
Akyem Abuakwa is one of the largest states of the Akan ethnic group in Ghana. Notwithstanding its size and important contribution to Ghana's development, historians have paid little attention in doing academic research on the health history of the people. Using a qualitative method of research, this paper does a historical study on public health policies in Akyem Abuakwa from the 1850 s to 1957 . We utilised documentary and non-documentary sources to discuss the various public health policies implemented in Akyem Abuakwa from the pre-colonial era to the colonial era. We examined the impact of the policies on the people of Akyem Abuakwa and the various challenges faced by the British colonial administration in their quest to implement public health policies.
\end{abstract}

KEY WORDS: Akyem Abuakwa, Ghana, Gold Coast, history, Public Health 
Samuel ADU-GYAMFI - Phinehas ASIAMAH - Benjamin Dompreh DARKWA - Lucky TOMDI

Public Health Policies in the Akyem Abuakwa of Ghana (1850-1957)

\section{Introduction}

Preventive health measures should be the utmost priority for any population seeking to achieve good health. The World Health Organization (WHO) defines preventive health measures as "all organized measures (whether public or private) to prevent diseases, promote health and prolong life among the population as a whole" (ADU-GYAMFI - DRAMANI AMAKYE-BOATENG - AKOMEAH 2017:1-2). The Centre for Disease Control (CDC) also defines public health as the science and art of preventing diseases, prolonging life and promoting health through organised efforts (CENTER FOR DISEASE CONTROL 2018). Historical ideas, trial and error, and the development of basic sciences, technology and epidemiology influenced the development of public health (TULCHINSKY VARAVIKOVA 2014:1). The definition and understanding of diseases differs among communities across the globe. This is because of the medical, religious and natural philosophical ideas of the groups, their resources and the changing circumstances in which they lived (BERRIDGE 2016:19).

The earliest explanation to diseases and epidemics among the earliest civilizations were rooted in mythology, superstition, and religion (BOSTON UNIVERSITY: A BRIEF HISTORY OF PUBLIC HEALTH 2018). During the middle ages, explanation to diseases became more scientific even though theology and mythology were inextricably intertwined with the culture and belief systems of the people (TULCHINSKY - VARAVIKOVA 2014:30). In his article "Sanitation, Bath and Street-Clearing in the Middle Ages and Renaissance", Thorndike reports that, among the many criticisms levelled against the medieval era, three of them were slanderous. They include: first, constant foul smell and filth in towns; second, soap and bath were scarcely known in the medieval Europe; third, there was over-crowding in several of the towns and cities (THORNDIKE 1928:192). He further argued that these accusations from different academics lacked enough evidence.

The physiological school of thought was developed within the medieval period, which maintained that good health as well as fighting illness depended on natural causes thus, health and diseases could not be dissociated from the physical and social environment. This called for the implementation of certain social health policies (TOUNTAS 2009:13). The Cretes for instance have been applauded by Tountas as the earliest civilization to use underground clay pipes for sanitation and water supply. They also created public latrines and introduced the ontological streets system (streets that are perpendicular to each other) to ensure proper spacing (TOUNTAS 2009:15). The bubonic plague that spread across Europe from 1347 to the 1700's changed the idea of thinking and explaining diseases (GRISSOM 2004:14). During the plague, many scientific theories were developed to explain its causation. 
Samuel ADU-GYAMFI - Phinehas ASIAMAH - Benjamin Dompreh DARKWA - Lucky TOMDI

Public Health Policies in the Akyem Abuakwa of Ghana (1850-1957)

Systematic approaches were developed in the cause of the plague to curtail it. Doctors were clothed from hair to toe including the use of hood and mask in order to protect them from contracting the disease (GRISSOM 2004:52). The preparation of concoctions and decoctions also became very predominant at the time in an attempt to stop the plague. Quarantining and isolation also became very useful as an approach to curtail the spread of the disease (GRISSOM 2004: 56).

In Africa, before colonization, public health policies were in the hands of chiefs and indigenous priest healers. These policies were implemented through certain social control mechanisms like taboos and other related customs (ADU-GYAMFI - BRENYA - EGYIR 2017:3). Many pre-colonial African societies adopted preventive health care strategies to meet the health of their populations. The Khoisan population in South Africa for instance adopted a strategy of moving from their original location or homes to different places to avoid mosquito bites which caused malaria. This protected their population from other environmental related condition and diseases due to the vagaries of the weather. They settled on high mountainous regions especially, during the rainy seasons and returned to their former location when the prevailing conditions were not detrimental to their health and well-being (JANZEN - GREEN 2017:6).

Addae argues that the establishment of permanent settlements in Ghana along the coast marked the beginning of European exposure to local diseases (ADDAE 1997:11). Similarly, Patterson is of the view that the forts and castles became the centre of many illnesses like yellow fever and malaria among others (PATTERSON 1981:33). Tracing the evolution of Western healthcare in Ghana, he stated that the beginning of modern health care in Ghana can be traced to the latter part of the 19th century (PATTERSON 1981:11). Ofosu-Amaah has argued that during the first European contacts in the Gold Coast, the Europeans suffered from several health challenges which called for new strategies that formed the bases of Western healthcare in the Gold Coast since the fifteen century (OFOSU-AMAAH 2005:184$185)$.

Twumasi reports that the beginning of Ghana's Western medical service extends back to 1844 , the period when medical doctors were for the first time posted to the Gold Coast to administer health care to the colonial administration (TWUMASI 1975:62). On the contrary, Alatinga and Williams have reported that, the historical development of Western health care in Ghana began in the 1920's (ALATINGA - WILLIAMS 2014:8). Significantly, the works of Addae and Twumasi also reveal that, the activities of Christian missionaries in the field of medicine cannot be ignored in Ghana's health history. Many Christian missions that came to Gold Coast initially gave little medical training to their missionaries in order for them to deal 
Samuel ADU-GYAMFI - Phinehas ASIAMAH - Benjamin Dompreh DARKWA - Lucky TOMDI

Public Health Policies in the Akyem Abuakwa of Ghana (1850-1957)

with certain minor illnesses. Many of these missionaries extended their medical knowledge to help the native population. Addae for instance argues that Thomas Birch Freeman, a missionary of the Wesleyan mission of the Gold Coast treated the Paramount Chief of Juabeng with the little medical knowledge he had acquired (ADDAE 1997: 8-11). Addae studied the sanitary conditions of the Gold Coast and concluded that before the 1880s, the towns along the coast were ill-famed for their poor and improper sanitation (ADDAE 1997: 8-11). The insanitary condition led to the outbreak of many diseases which increased European mortality in the Gold Coast. As a result of the increasing European mortality, the colonial administration began to institute proper health measures against diseases which threatened the lives of Europeans.

Twumasi has noted that the causes of many health problems in the Gold Coast were rooted in the environment, poor sanitation, and malnutrition (TWUMASI 1975:349). The harsh environmental conditions notwithstanding, Addae has reported that "it was possible for the Chief of Elmina (Caramansa) and his family as well as some other elders to receive some sort of medical assistance or care from Diego Azambuga at the castle, in order to strengthen their bond shortly after the arrival of the Portuguese" (ADDAE 1997:11). Again, he argued that European doctors like Dr. Pieter and Dr. Paul Isert extended their assistance to the local Africans even though it was not their primary objective. This according to Addae marked the earliest attempt of practicing Western medicine in Ghana.

It is important to note that though Western medicine was extended to the native population during the first phase of European contact with the Gold Coast, their primary concern was to meet the health needs of their subjects. Closely linked to this, Senah has categorized the introduction of Western medicine in Ghana into three phases. He used the term "Medical Apartheid" to refer to the period from 1471 to 1844 which is the period where Europeans received separate medical attention. The second phase was the signing of the Bond of 1844 which marked the earliest beginning of British control on the coast (1844-1900). The Bond of 1844 was a formal agreement made between some Fante chiefs of the Gold Coast and the British government. The bond marked the period when the British imperial power assumed formal control of the coastal territory of the Gold Coast (GOCKING 2005:25). The third phase was the colonial period (1900-1957). This was the period the colonial government took charge of the administration of the Gold Coast (SENAH 2001:83).

Arhinful has argued that "the main aim of the European medical officials in the Gold Coast was first to treat the European officials and other Europeans, followed by the African civil servants in colonial civil service and paid little attention to the native population" (ARHINFUL 2003:32). In 1850, the secretary of state for the colonies Earl Grey proposed a

DOI: 10.2478/eas-2021-0014 @ University of SS. Cyril and Methodius in Trnava. All rights reserved. 
direct taxation to supplement customs duties to raise additional revenue for social infrastructure such as schools, hospitals, roads and sanitation (ARHINFUL 2003:29). According to Knoll Grey, Earl Grey realised that the direct taxation without regular government in the territory will achieve nothing, so he decided to do so only with the general consent of the chiefs and their people at the coast (KNOLL 1967: 417). In 1852, Governor Stephen J. Hill succeeded in getting some Fante chiefs to form a legislative assembly and a poll tax of one shilling per head was levied on the people in places under British protection in the south (ARHINFUL 2003:30). Part of the tax was used for medical purposes. Arhinful argues that, the activity did not last as a result of general opposition from the native Fantes. He further argues that health care within this period was not based on out of pocket cost for individuals within the territory of the Gold Coast (ARHINFUL 2003:30). Ofusu-Amaah has also reported that, the abolishment of the poll tax in relation to health care meant that the government had to devise a strategy to finance health services (OFOSU-AMAAH 2005:187). During this period, Western medicine was given much attention by the British colonial administration over traditional medicine and the natives gradually showed interest in same (OFOSU-AMAAH 2005:183). As the colonial administration expanded, it became a necessity to train the natives in the medical field to assist in healthcare delivery.

In 1877, the administrative capital was transferred from Cape Coast to Accra and this marked an important change in Ghana's medical history (ADDAE 1997:86). The Towns, Police and Public Health Ordinance of 1878 was the first official public health policy to be implemented in the Gold Coast in Accra, Cape Coast, and Elmina (ANDERSON - COHEN 2016:55). Inspectors and surveyors were sent to these towns to ensure the successful implementation of the new ordinance (ADDAE 1997:87). This was followed by the Quarantine Ordinance of 1891 and the Dispensary and Sale of Drugs and Poisons Ordinance (ARHINFUL 2003:3032). In 1909, the Department of Health was created with two sections: the medical and the sanitary divisions. They were in charge of the health needs of the people of the Gold Coast. The colonial administration within this period aimed at disease prevention and also made gains in curative medical practice. European health care policies which also affected Asante and the modern day Eastern Region of Ghana including Akyem Abuakwa became even more pronounced.

Akyem Abuakwa is one of the largest states of the Akan ethnic group. Notwithstanding its size and important contribution to Ghana's development, historians have paid less attention to do academic research on the health history of the people. Major works on the Akyem Abuakwa have been largely centred on the socio-political history of the people with limited attention to their health history. Addo-Fenning studied the origin and evolution of the various 
Samuel ADU-GYAMFI - Phinehas ASIAMAH - Benjamin Dompreh DARKWA - Lucky TOMDI

Public Health Policies in the Akyem Abuakwa of Ghana (1850-1957)

Akyem states and how such development impacted the politics of the people (ADDOFENNING 1988). He again focused on the military history of the Akyem Abuakwa from the 1700's to 1918 (ADDO-FENNING 1998). Gray also studied the legal history of witchcraft in Akyem Abuakwa during the colonial period (GRAY 2000). Ofusu-Mensah also focussed on the mining history of the Akyem Abuakwa (OFOSU-MENSAH 2017). To emphasize, the public health history of the Akyem Abuakwa has received little or no scholarly attention. It is therefore essential to pay particular attention to the health history of Akyem Abuakwa particularly, public health policies since the colonial period.

The people of Akyem Abuakwa as stated earlier belong to the Akan ethnic group and traditionally believe in ancestral worship. They have traditional stools which represent the emblem of their traditional sovereignty. The modern territory of Akyem Abuakwa comprises over 3,120 square miles of land. Its boundaries are marked by river Pra, Asante, New Juabeng and Krobo to the West, Asante Akyem to the Northwest, Kwahu to the North, and Agona to the South. Akyem Abuakwa is an agrarian community due to its large forests. Cocoa farming is the main agricultural activity of the people. However, they also engage in other economic activities including mining, trading and other tertiary economic activities (NYARKO 2018:1 2).

The map below describes the various towns and boundaries of Akyem Abuakwa.

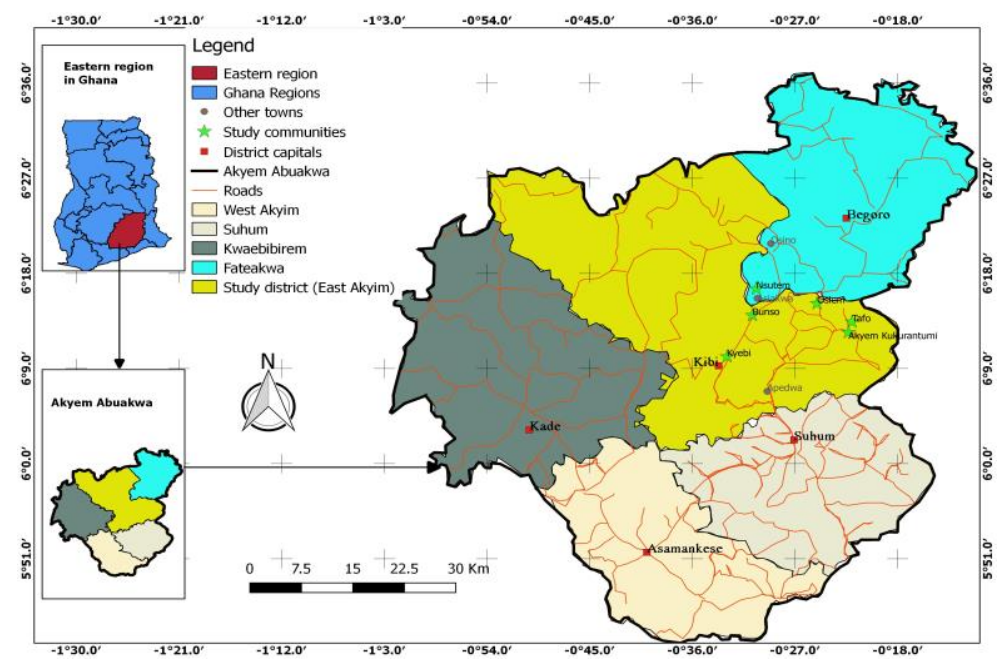

Figure 1: Map of Akyem Abuakwa. Source: Department of Geography and Rural Development, Kwame Nkrumah University of Science and Technology (KNUST), Kumasi 2021. 
This paper is based on a qualitative research approach. Information was taken from both primary and secondary sources. Concerning primary sources, data was collected from the Public Records and Archive Administration Department (PRAAD) at the regional (Koforidua) and national (Accra) level to help develop a useful historical analysis and a synthesis of public health policies since the colonial period. Also, several palace officials and the elderly were randomly sampled and interviewed. We deemed palace officials and the aged as the most reliable source of information for this contribution. The key informants were above 60 years old and have firm knowledge on the traditional systems of public health within the pre-colonial period. Secondary data was taken from various published books and journal articles. The books and articles provided information on the various themes including: The History of Public Health in Africa, Evolution of Modern Health Care in Ghana and Public Health Policies in Ghana. Fifty respondents were interviewed for the study. Out of the fifty, six people were palace officials from various towns including Akyem Kukurantumi, New Tafo, Sokodeguaso, Kyebi and Akyem Asafo. To emphasize, these respondents are nuanced in the traditions of Akyem Abuakwa.

The paper is organized into two sections. The first section deals with the introductory concept of the study which comprises the introduction including matters arising from the literature and problematization of the study. The second section is devoted to discussions and narratives on traditional and Western public health strategies and policies in Akyem Abuakwa. Major themes include traditional public health policies of Akyem Abuakwa from the 1850's to 1910. The others include colonial public health policies with sub-themes: Building of slaughter houses as a preventive health care strategy; Infectious Disease Ordinance of 1908; Institutional response as a preventive health care strategy by the colonial administration: The Housing and Town Planning Ordinance, Mosquito Ordinance, Mining Health Areas Act, Forest Ordinance and Reserved Ordinance. The second section also discusses the difficulties faced by the colonial administration in ensuring public health care. From here, we draw a conclusion to the study by highlighting key issues arising from same.

\section{Traditional Public Health in Akyem Abuakwa (1850-1910)}

Traditionally, public health was under the directives of the traditional institution. The traditional institutions' primary concern was to ensure the social, economic and spiritual wellbeing of their subjects (ADU-GYAMFI - DRAMANI - AMAKYE-BOATENG AKOMEAH 2017:4). Arhin has argued that, the establishment of the various traditional rules 
Samuel ADU-GYAMFI - Phinehas ASIAMAH - Benjamin Dompreh DARKWA - Lucky TOMDI

Public Health Policies in the Akyem Abuakwa of Ghana (1850-1957)

in the form of taboos, customs and laws helped to promote sanitation prior to European presence and colonisation (ARHIN 1985:35). The subsequent paragraph brings to light some traditional public health policies enacted by the traditional institutions (chieftaincy) and the British colonial administration. This was enforced by the native authorities including chiefs and headmen.

\section{Taboos}

According to Okyeame Obeng, the linguist of the Queen mother, Nana Hemaaa Akua Dokuah of the Adonteng division of Akyem Abuakwa, "taboos have been the most preventive strategy employed by our forefathers to govern or control all spheres of life including health" (OKYEAME OBENG, personal conversation, $10^{\text {th }}$ February 2020). In Akyem Abuakwa, taboos that were directed towards the improvement of health and environmental sanitation persisted. Obaapanyin Esther Asare, an eighty-two-year-old woman and a member of the Asona Royal family gave an account of some public health taboos in Akyem Abuakwa. She hinted that:

"During the time of our forefathers (Nananom), it was a taboo in Akyem Kukurantumi for one to untidy his or her compound. The rationale behind this was that the town deity Nobuo Kofi was neat and its subjects were expected to do same. Failure to comply meant failure of the deity to meet their spiritual and material needs, and other expectations. Also, it was a taboo to sing while bathing. Failure to comply meant that the person's mother could face a death penalty. Ideally, the scientific rationale behind this was that these traditional soaps have high chemical contents that can cause harm to the human body when it enters the mouth. Individuals who did not talk while bathing were believed to gain the protection and covering of the deities" (OBAAPANYIN ESTHER ASARE, personal conversation, $10^{\text {th }}$ February 2020).

Opanyin Ofori, an 82 year old retired Agricultural Extension Officer made reference to the role of ancestral spirits in dictating the essence of practicing good sanitation to the natives of Akyem Abuakwa. He hinted that there is a general belief that ancestors and other spirits do visit various households on regular basis. Our informant further reported that, when these ancestral spirits visit an untidy compound, they do not visit same location again. This deprived the household from the benevolence of the deities. If an individual within this period complied with these taboos, his health and well-being was assured (OPANYIN OFORI, personal commination, $14^{\text {th }}$ February 2020). From this, it can be inferred that taboos served as the guide toward ensuring good health and well-being of individuals within the traditional 
Samuel ADU-GYAMFI - Phinehas ASIAMAH - Benjamin Dompreh DARKWA - Lucky TOMDI

Public Health Policies in the Akyem Abuakwa of Ghana (1850-1957)

society. Taboos imposed lower penalties that were nonetheless sufficient to deter individuals from thinking about the option to deviate (FERSHTMAN - GNEEZY - HOFFMAN 2011:1).

Concerning superstition, Opanyin Asare, a member of the Asona Royal family and a retired Agricultural Extension Officer hinted:

"All our customs indeed have strong spiritual backings. Failure to do so attracts some form of punishment from our gods. Therefore, all aspects of life of our forefathers were entangled with spiritual things and this also put fear in the people. It was a taboo in Akyem Abuakwa to fetch water from certain streams and rivers. These rivers, I was told were basically for the gods and not for humans. In Akyem Kukurantumi, there is a river called "plebe". It was a taboo to fish, swim or fetch water for domestic purposes in this river. The general belief is that, the river belongs to the gods" (OPANYIN ASARE, personal communication, $12^{\text {th }}$ February 2020).

However, our informant hinted that the river contained certain waterborne diseases like elephantiasis and bilharzia (Schistosomiasis) among others. Therefore, to prevent people from being infected by such diseases, their forefathers made it a taboo to prevent people from having access to the river. Any breach of same attracted some form of punishment by the gods (OPANYIN ASARE, personal communication, $12^{\text {th }}$ February 2020). It can also be deduced from the words of Opanyin Asare that the traditional societies understood that, attaching spiritualism to certain social norms and taboos could compel the people to follow such norms. Similarly, Fershtman, Gneezy and Hoffman have posited that "human behaviour is not governed only by rational decision making" (FERSHTMAN - GNEEZY - HOFFMAN 2011:1).

Also, in Akyem Abuakwa, there were traditionally created holidays for workers especially farmers. These traditional holidays are known as dabone which literally means a strange day (OBAAPANYIN KWOKWE, personal communication, 12 ${ }^{\text {th }}$ January 2020). According to Opanyin Obeng, during those designated holidays, no one was expected to go to farm. The rationale was that, dabone was a day for the various town deities and other spiritual forces to embark on certain spiritual operations. It was possible to meet these spirit beings when one goes to farm during dabone. In the olden days, when an individual breached this rule, he did so at his own peril (OKYEAME OBENG, personal communication, $14^{\text {th }}$ February 2020). From this, it can be deduced that there was a scientific rationale behind the creation of dabone. It was to ensure enough rest among farmers and also allow the land and sometimes the rivers some fallow period to replenish. Pre-colonial people of Abuakwa believed that working without rest had negative health implications on the body. To buttress this point, our 
Samuel ADU-GYAMFI - Phinehas ASIAMAH - Benjamin Dompreh DARKWA - Lucky TOMDI

Public Health Policies in the Akyem Abuakwa of Ghana (1850-1957)

informant, Obaapanyin Esther Asare, hinted that: "apart from ensuring proper rest among farmers, dabone was established by our forefathers to serve as a day where every household was entitled to embark on general cleaning in various households. The old women have shared that, in their childhood years, they witnessed individuals cleaning their houses during dabone" (OBAAPANYIN ESTHER ASARE, personal communication, $14^{\text {th }}$ February 2020). According to her, it was not mandatory to embark on a general cleaning during dabone but it became a norm in Akyem Abuakwa for each household to embark on general cleaning exercise during that period. This is consistent with the work of Kosoe, Diawuo Darko and Osumanu who argue that foda or dabone was to ensure that farmers and fishermen stayed home within the week to rest and allow some period for the natural environment, animals and fish in rivers and streams among others to regenerate (KOSOE - DIAWUO DARKO OSUMANU 2019:14).

\section{Traditional Medicinal Approach as Preventive Health Care Strategy}

Ozioma and Chinwe argue that, traditional medicine is "viewed as a combination of knowledge and practice used in diagnosing, preventing and eliminating diseases. This may rely on past experience and observation handed down from generation to generation" (OZIOMA - CHINWE 2019:191). This statement is applicable to pre-colonial Akyem Abuakwa since the people used knowledge and experience in diagnosing and preventing diseases. Here, attention is paid to the use of concoction and other traditional herbs which were predominant during the pre-colonial era. This concoction is popularly known in Twi as $d u d o$. According to Opanyin Ofori, it was a kind of immune system booster which helped to protect the body from certain diseases (OPANYIN OFORI, personal communication, $14^{\text {th }}$ February 2020). This pre-colonial practice still persists in traditional communities in Africa and Ghana in particular in contemporary times. According to Obaapanyin Esther Asare, in the past, every household had what is called mukyia (a local stove used for cooking) in front of their house. The concoction was boiled or heated on the mukyia and everyone in the house was expected to drink from a calabash before the start of a daily activity (OBAAPANYIN ESTHER ASARE, personal conversation, $14^{\text {th }}$ February 2020). This concoction consists of a mixture of herbs and bark of trees that were boiled in water. In some places, the pots were placed in front of the house covered with calabash and everyone passing by or entering the house could drink some.

Another important medical practice was kumkuma. Kumkuma was a traditional medicinal practice in Akyem Abuakwa prior to colonisation. According to Opanyin Ofori, this practice 
Samuel ADU-GYAMFI - Phinehas ASIAMAH - Benjamin Dompreh DARKWA - Lucky TOMDI

Public Health Policies in the Akyem Abuakwa of Ghana (1850-1957)

was occasional and was deployed when there was an outbreak of an epidemic (OPANYIN OFORI, personal communication, $14^{\text {th }}$ February 2020). During the outbreak of an epidemic, the chief priest with the help of the 'gong-gong beater' or the traditional announcer, announced or called for an emergency meeting at the shrine on a specific date (OKYEAME OBENG, personal communication, $14^{\text {th }}$ February 2020). According to Okyeame Obeng, kumkuma is a product of a tree known in the Akan language as nyame dua, which is also referred to botanically as Alstonia boonei. Preparing the kumkuma required that the healer made a hole in the trunk of a tree which was placed at the centre of the shrine. The medicine was poured in the kumkuma and natives were given the medicine to drink (OKYEAME OBENG, personal communication, $14^{\text {th }}$ February 2020). This was only practiced by the chief priest and other experienced herbalists. According to Obaapanyin Kwokwe, the practice was effective and it prevented many people from contracting certain infectious diseases especially during the small pox outbreak in Akyem Abuakwa. The practice of kunkuma had some spiritual meaning (OBAAPANYIN KWOKWE, personal communication, $12^{\text {th }}$ January 2020). The relics of these practices exist in contemporary Akyem Abuakwa. Significantly, some of these practices have been refined to meet the changing trends in society.

\section{Communal Labour as a Preventive Health Care Strategy}

According to Asamoah, communal labour is placed within the wider concept of community development which is based on the principle of self-help, felt needs and participation (ASAMOAH 2018:13). According to Opanyin Ofori, communal labour was based on the principle of individual responsibility that metamorphosed at the community level (OPANYIN GEORGE OFORI, personal communication, $14^{\text {th }}$ February 2020). Similarly, Bhattacharyya has reported that, "the principle of self-help rests on a concept of human beings; when they are healthy they are willing and able to take care of themselves and reciprocate" (BHATTACHARYYA 2004:22). They are also productive, more predisposed to give than receive, active rather than passive, and creative rather than consuming (BHATTACHARYYA 2004:22). In Akyem Abuakwa, it was called oman adwuma or asafo adwuma and it was one of the most effective techniques in ensuring proper environmental sanitation.

Our informant, Obaapanyin Asare hinted that, during the pre-colonial days, rubbers, containers and industrial wastes among others were not common. The only communal activity within this period was 'general weeding'. In view of this, the chiefs made proper arrangement concerning proper organisation to ensure its effectiveness (OBAAPANYIN 
Samuel ADU-GYAMFI - Phinehas ASIAMAH - Benjamin Dompreh DARKWA - Lucky TOMDI

Public Health Policies in the Akyem Abuakwa of Ghana (1850-1957)

ESTHER ASARE, personal conversation, $14^{\text {th }}$ February 2020). Opanyin Ofori gave a detailed account on how communal labour was organised during the pre-colonial period. $\mathrm{He}$ hinted among other things that, it is the chief's responsibility to conduct communal labour in consultation with his elders and a public announcement on the specific date to carry out such exercise. The chief calls the mmrantehene (youth leader) to start initial preparation of mobilising the youth to embark on the exercise. On the stipulated day, the leader of war known as the asafo akye leads the people to the meeting place or grounds. The chief then informs the asafo akye through the asafopiti (the linguist of the Asafo akye) concerning the exercise about to be carried out. If the asafo akye consents to the chief's decision, it means the exercise can be carried out and if he does not, it means the exercise cannot be carried out (OPANYIN OFORI, personal communication, $14^{\text {th }}$ February 2020). Addo-Fenning has noted that, "the Abuakwa Asafo Akye during the late $19^{\text {th }}$ and $20^{\text {th }}$ centuries, enjoyed the confidence and loyalty of their Asafo and the people and often acted independently and in defiance of the chiefs" (ADDO-FENNING 1998:14). He opines that, this development was due to the changing circumstances surrounding the socio-political environment of Akyem Abuakwa during the period under review. Formal education played a leading role in changing the sociopolitical environment in Akyem Abuakwa (ADDO-FENNING 1998:15). According to Obaapanyin Wukubea, there were special groups charged with monitoring and supervision. These people reported indirectly to the chief through the mmrantehene. Failure to attend such clean-up campaigns attracted a heavy fine (OBAAPANYIN WUKUBEA, personal communication, $6^{\text {th }}$ 2020). This practice has remained the most effective technique of ensuring proper community sanitation in recent times. This policy of self-help can be integrated into current society to ensure the protection of the environment and proper sanitation in particular.

\section{Colonial Public Health Policies in Akyem Abuakwa (Preventive Health Care Policies)}

\section{Building of Slaughter Houses as Preventive Health Care Strategy}

The slaughter house policy was restricted to large towns in Akyem Abuakwa including Kyebi (the administrative capital of Akyem Abuakwa), Tafo, Suhum, Begoro, Kade and Kukurantumi (PRAAD, Accra, C.S.O 558/311, 1934). The provision was made in accordance with Cap 86 of the Town Act of 1892 sections 24 and section 25 of the Town 
Samuel ADU-GYAMFI - Phinehas ASIAMAH - Benjamin Dompreh DARKWA - Lucky TOMDI

Public Health Policies in the Akyem Abuakwa of Ghana (1850-1957)

Ordinance Act of 1934 which required the provision of slaughter houses and markets within any region under colonial control (PRAAD, Accra, C.S.O/833/33, 1933). Opanyin Ofori gave a detailed account on the rationale behind the building of a slaughter house at Kyebi. He hinted;

"I was told by my grandfather that, there was the development of a large manyanka (slaughter house) especially by the Northerners (Eseremu Fuo). According to my grandfather, upon a visit to the Kyebi market at the time, animals were displayed publicly, attracting flies and other harmful insects. The place had an unpleasant smell, and sometimes most animals were slaughtered in various homes and places and later brought to the market for sale. This made it difficult for the health officers (tankase) to determine the state of health of these slaughtered animals at the time" (OPANYIN OFORI, personal communication, $14^{\text {th }}$ February 2020).

In support of this, the work of Adu-Gyamfi, Adjei and Owusu-Ansah postulates that, the rationale for implementing this policy during the colonial period was to ensure good and healthy living among the Gold Coasters. This was because slaughtered animals were under constant checks by the health officers to ensure that they were in good and healthy condition. Also, they ensured that a clean environment was maintained for mass purchasing (ADUGYAMFI - ADJEI - OWUSU-ANSAH 2013:227).

In 1934, the Colonial Health Board established the Kyebi slaughter house (PRAAD, Accra, C.S.O 558/311, 1934). Under the slaughter house policy, there was the existence of slaughter house regulations under section 20 of the slaughter house ordinance, to ensure proper sanitary and hygienic standards in the respective slaughter houses (PRAAD, Koforidua, New Juabeng Native Authority, 1948). The regulations were as follows:

- No person shall slaughter any cattle or other animals for human consumption in any of the town specified in the schedule to these rules or within the precinct of such towns (Towns in Akyem-Abuakwa) otherwise than in the public slaughter houses.

- No person shall sell any meat not killed in the specified slaughter houses.

- A health officer or any person employed by the native Authority has the sole power to exercise control of the slaughter house to ensure proper sanitation of the place and healthy meat to be consumed.

- Every person who shall make use of a slaughter house or other place appointed for the slaughter of animals shall keep the same in a clean state and shall before leaving 
briefly sweep and clean all dirt, blood, offal and rubbish and shall wash and clean the slaughter house to the satisfaction of their health officer.

- No person shall be permitted to use a slaughter house or other place appointed for the slaughter of animals until he shall have paid such fee's as may from time to time be fixed by resolution of the Native Authority and approved in writing by the Chief Commissioner to the person employed by the Native Authority to receive the same.

- Any person contravening or failing to comply with any of these rules shall be guilty of an offense and shall be guilty of an offense and shall on conviction to a fine not exceeding 5 pounds or imprisonment not exceeding one month (PRAAD, Koforidua, New Juabeng Native Authority, 1948)

It is important to state that the 1948 Slaughter House Ordinance was a repetition and amendments of the old ordinances concerning same. To ensure that this policy was properly enforced to achieve its desired objective, the colonial administration made several amendments. They included the 1909 slaughter house amendment Act in which section 8 of clause 7 was amended, the 1921 slaughter house amendment act where section 70 of clause 10 was amended and section 5 of clause 17 of 1921 Slaughter house amendment Act was also amended. These amendments were made to ensure that the policies were effectively implemented in Gold Coast and Akyem Abuakwa in particular (PRAAD, Accra, Cap 86 Towns Act, 1892 arrangement of sections). For example, the literature on public health including Adu-Gyamfi, Adjei and Owusu-Ansah among others reveal that, these policies coupled with their consistent amendments promoted the health of the native population during the colonial period (ADU-GYAMFI - ADJEI - OWUSU-ANSAH 2013:4).

\section{Infectious Disease Ordinance of 1908}

This ordinance was a general health ordinance for the entire Gold Coast colony and became very useful during the influenza pandemic outbreak. It was enacted by the governor of the Gold Coast Colony with the advice and consent of the legislative council (PRAAD, Accra, ADM.4/1/56, 1927). The ordinance provided for the prevention of the spread of infectious diseases, the settlement of claims for compensation and damages in connection with measures taken to prevent the obstacles of communicable nature and for related matters (PRAAD, Accra, Infectious Disease Act, 1908). The ordinance entrusted into the hands of the Health Department an independent power, the right to adopt emergency measures as might be considered necessary and undoubtedly received the full support of all political 
Samuel ADU-GYAMFI - Phinehas ASIAMAH - Benjamin Dompreh DARKWA - Lucky TOMDI

Public Health Policies in the Akyem Abuakwa of Ghana (1850-1957)

officers. Under this ordinance, the Director of Health in the various provinces had the sole right to declare an area infected (PRAAD, Accra,No. 454/32,1932). In a personal conversation with Obaapanyin Esther Asare, she hinted that, in Kyebi and other principal towns including Suhum, Bunso among others, there was the creation of temporal structures where the infected were quarantined and treated to reduce the spread of the disease (OBAAPANYIN ESTHER ASARE, personal conversation, $14^{\text {th }}$ February 2020). We infer that, this came into being as a result of the Infectious Diseases Ordinance that granted power to all health workers to take any action necessary with the support of the colonial political institutions and interest groups.

\section{Institutional Response as a Preventive Health Care Policy and Strategy by the Colonial Administration}

As a result of the insanitary condition in Akyem Abuakwa, the colonial administration created a public health institution to help provide remedy to the situation (PRAAD, Accra, C.S.O 11/14/205, 1933). The administration created health boards that were hierarchical. These were as follows: the first was the Central Health Board; the second was the Provincial or District Health Boards and lastly the Town Health Boards (PRAAD, Kumasi, C.S.O/14/172, 1933). The Town Health Board was basically the sanitary committee established under the Provincial Health Boards (PRAAD, Accra, M.P No. 1301/1926, 1932). Under the Provincial Health Board, there was the creation of the Akyem Abuakwa Health Board. The Board was responsible for the running of the day-to-day health affairs in the District. The Health Board operated under the directives of the Provincial Commissioner upon the advice of the Senior Health Officer in Akyem Abuakwa (PRAAD, Accra, C.E.P,No.1053/1428/21, 1932). The Board was made up of the District Commissioner (president), the Assistant Director of Medical Service, the Senior Sanitary Officer (Director of Public Health) and the Provincial Engineer, with other supporting staff (PRAAD, Accra, C.E.P,No.1053/1428/21, 1932).

Later, executive engineers replaced provincial engineers in Akyem Abuakwa as members of the board (PRAAD, Accra, C.S.O/14/172, 1932). Also, the office of the Provincial Engineer responsible for waste management was replaced with the Public Health Department. The Town Health Board was established in various towns within the province and was under the control and supervision of the Provincial Health Board (PRAAD, Accra, C.S.O/14/172, 1932). Mr. Esihene, a retired District Chief Executive of East Akyem Municipal Assembly brought to light the Old established towns within the colonial period. He hinted: "when we 
Samuel ADU-GYAMFI - Phinehas ASIAMAH - Benjamin Dompreh DARKWA - Lucky TOMDI

Public Health Policies in the Akyem Abuakwa of Ghana (1850-1957)

talk about towns within this period, emphasis was made on Kyebi, Kukurantumi, Osiem, Asafo, Akooko, Begoro and Asiakwa. It is possible that Health Boards were established within these towns" (EMMANUEL ASIHENE, personal conversation, 16 ${ }^{\text {th }}$ February 2020). Adu-Gyamfi, Adjei and Owusu-Ansah have noted that, the Town Health Board was made up of a health officer, sanitary inspector, a secretary, an office clerk, messengers and cleansers. The others included, the latrine and incinerator workers, each with designated functions (ADU-GYAMFI - ADJEI - OWUSU-ANSAH 2013:228).

Significantly, concerning Akyem Abuakwa, the duties of the Akyem Abuakwa Health Board under the Health Board Ordinance were as follows:

- To submit to the central board (at Accra) any policy or scheme which may be initiated in the interest of the public health within Akyem Abuakwa.

- $\quad$ To serve as an advisory body to the central health board upon any scheme or works affecting the public health within Akyem Abuakwa.

- $\quad$ To require the attendance of any official resident within Akyem Abuakwa who may have special knowledge of any matter under consideration.

- To submit a copy of each meeting to the central health board (PRAAD, Accra, C.S.O 11/14/205, 1932).

These functions were assigned to the Health Board to ensure that health policies were effectively implemented from the grass root level to major centers in Akyem Abuakwa. The designation of these functions to the Board and its collaborative role with the Central Health Board especially on advisory matters epitomised a strong system of decentralisation that had the proclivity to help promote health care at the grass root level during the colonial period. Certainly, effective devolution of power in the healthcare management in Ghana in contemporary times can also advance her gains in public health.

\section{The Housing and Town Planning Ordinance}

As Adu-Gyamfi, Adjei and Owusu-Ansah have stated, the housing and the town planning ordinance in the Gold Coast came into being to ensure proper housing arrangement to prevent congestion, stuffiness and also to improve ventilation (ADU-GYAMFI - ADJEI - OWUSUANSAH 2013:225). The ordinance emanated from the 1926 Town Amendment Ordinance. It was applied in Akyem Abuakwa due to the insanitary conditions in the area (PRAAD, 
Samuel ADU-GYAMFI - Phinehas ASIAMAH - Benjamin Dompreh DARKWA - Lucky TOMDI

Public Health Policies in the Akyem Abuakwa of Ghana (1850-1957)

Accra, and C.S.O 11/14/205). In 1933, a memorandum was submitted to the governor by the Paramount Chief of Akyem Abuakwa during a durbar with the sub-chiefs and the natives. They reported among other things that:

- The sanitary condition of Kyebi and its surroundings was not satisfactory. All that was required was sound rural method of sanitation

- Secondly, the perimeter of the town was too overgrown and covered with much filth and indestructible refuse.

- The prevailing system of pit-latrines, and the total lack of such convenience in some areas constituted an insufferable nuisance

- Poor disposal of indestructible refuse required some proper organization.

On 15th December 1933, the Governor of the Gold Coast received a report concerning the sanitary condition in Kyebi. The report made strong emphasis on the poor housing condition in the Kyebi community. It stated among other things that buildings were commenced and altered without any previous building permits. Many of the houses were in bad state of repair (PRAAD, Accra, C.S.O 11/14/205, 1933). Upon the submission of the memorandum to the governor and the report on the poor sanitary state of Kyebi, the colonial administration responded quickly to ensure proper health and general sanitation in the area. Under the 1926 Town's Amendment Ordinance, the Director of Public Health was granted power to make building regulations in the various municipalities in the colony including the various municipalities in Akyem Abuakwa. The Director of Public Health was to make a legal provision for the following; the level, width, the materials to be used for construction, building lines, and the layout of buildings, building sites and their suitability for dwelling houses, spaces to be left unbuilt around buildings in order to secure free ventilation. The others include the percentage area which may be covered with building, provision of passages, lanes and roads for the purpose of giving access to premises among others (PRAAD, Accra, AMD, 4/1/55, 1926).

Also, section 17 clause 2 of the 1926 Town Amendment Ordinance granted power to the District Commissioner in concurrence of the Director of Public Works or the Provincial Engineer to demolish any unauthorised building that was seen as a threat to the general public in Akyem Abuakwa (PRAAD, Accra, AMD, 4/1/55, 1926). The Director of Public Works with the advice of the Provincial Engineer proposed a new lay-out plan for Kyebi and was extended to other areas within Akyem Abuakwa (PRAAD, Accra, C.S.O/833/33, 1933). This plan came to be known as the G.C/.B/848 plan. Under this plan, the high street and the streets 
Samuel ADU-GYAMFI - Phinehas ASIAMAH - Benjamin Dompreh DARKWA - Lucky TOMDI

Public Health Policies in the Akyem Abuakwa of Ghana (1850-1957)

lateral to it was to be made parallel. Also, the side street was to meet the main street at a right angle. Section 32 clause 1 of the 1926 Towns Amendment Ordinance allowed the Director of Public Works in Akyem Abuakwa to make provisions in respect to overcrowding and the demolition of any building. In contemporary times, the literature on town and urban planning including the work of Hebbert among others have emphasized the importance of streets, access to building and how same are useful for public health and safety (HEBBERT 1999:437). However, the current state of layout of settlements in Akyem Abuakwa especially in Kyebi, Akyem Kukurantumi and Old Tafo are anathema to town planning. It is significant to adopt and improve upon some of these public health policies in Akyem Abuakwa in contemporary times to safeguard the health and well-being of the people (PRAAD, Accra, C.S.O/833/33, 1933).

\section{Mosquito Ordinance}

Another important ordinance that became effective in Akyem Abukawa was the mosquito ordinance. Malaria has been an endemic disease in the tropics since time immemorial. However, the predominance of mosquitoes in the Gold Coast including Akyem Abuakwa within the period under review can be attributed to the insanitary conditions that persisted at the time (ARHINFUL 2003:36). Strother argues that, the duty of the mosquito anti-brigade band was to embark on a door to door campaign with the effort to eliminate open water and encourage personal measures to protect against bites (STROTHER 2016:447). The gang consisted of a sanitary inspector, labourers and a police who ensured that the people followed the recommended measures (PRAAD, Accra, C.S.O/833/33, 1933). The sanitary inspector visited each compound once every fourteen days. To ensure that the people complied with the ordinance, larvae fine of 7/6d was imposed on offenders who were convicted (PRAAD, Accra, C.S.O/833/33, 1933). Preventive measures against malaria were implemented by the colonial administration especially in the 1930's (ARHINFUL 2003:36). This was due to the fact that, the reliance on curative health care alone could not fully eradicate endemic diseases that existed among the native population. 
Samuel ADU-GYAMFI - Phinehas ASIAMAH - Benjamin Dompreh DARKWA - Lucky TOMDI

Public Health Policies in the Akyem Abuakwa of Ghana (1850-1957)

\section{Mining Health Areas Act}

Another important health ordinance implemented within the colonial days at Akyem Abuakwa was the Mining Health Areas Act. This law operated in mining areas to ensure good health of workers and a good environment (PRAAD, Accra, ADM 4/1/56). Comparatively, in Nigeria, Nkwam has noted that due to improper sanitary measures in mining communities in British West Africa, mining areas became the centre of many communicable diseases. To alleviate this problem, there was the introduction of the Mining Health Ordinance (NKWAM 1988:15). Under this law, the mining companies were to make provision for the health needs of their workers in mining areas in British West Africa including Akyem Abuakwa.

In a personal conversation with Mr. Asihene, he hinted that, in Kyebi, Nsutam and Osino, mining pits were covered after a day's mining and the entire area was secured after same. This was done to ensure public safety (EMMANUEL ASIHENE, personal conversation, $16^{\text {th }}$ February 2020). Mining health centres in Akyem Abuakwa under the Mining Health Ordinance were expected to provide the town with public health accoutrements in order to enhance sanitation in these towns (EMMANUEL ASIHENE, personal conversation, $16^{\text {th }}$ February 2020). Opanin Ofori hinted that, public instruments like incinerators, dustbins and sick bays were provided by the mining companies (OPANYIN OFORI, personal conversation, $14^{\text {th }}$ February 2020). Kitula has lamented that, the impact of mining on the environment has been negative since environmental pollution has been a major challenge in most mining areas and this constitutes a threat to the health and well-being of human and animal species (KITULA 2006:409). Based on this, we argue that, the Mining Health Area Ordinance which was implemented in Akyem Abuakwa reduced many environmental problems that could serve as a serious threat to the health and social well-being of the natives.

\section{Forest Ordinance and Reserve Ordinance}

It has been scientifically proven that, proper vegetation provides a suitable weather condition that has positive impact on health (WORLD LIFE FUND 2020). As put forward by Amanor the Forest Ordinance was enacted basically to stop over exploitation to maintain the climate of the forest zone and watershed (AMANOR 1999:51). The colonial administration looking at the indiscriminate cutting of trees without any proper replacement and illicit mining in the Brim Forest Reserve compelled the colonial administration to implement the Forest 
Samuel ADU-GYAMFI - Phinehas ASIAMAH - Benjamin Dompreh DARKWA - Lucky TOMDI

Public Health Policies in the Akyem Abuakwa of Ghana (1850-1957)

Ordinance of 1910 and the Forest Reserve Ordinance of 1937 in the Gold Coast and Akyem Abuakwa in particular (PRAAD, Kofiridua, SCRER.231/41). The main objective of the Forest Ordinance was to limit the destruction of the Brim forest through activities such as mining and lumbering. The Forest Ordinance was to create a forest reserve for future purposes. These two ordinances brought about suitable weather conditions, clean and healthy water bodies among others. This impacted positively on the lives of the people of Akyem Abuakwa. Making this policy a priority, the colonial administration created the office of the Forest Commissioner and Reserve Commissioner respectively to ensure effective operation of this policy (PRAAD, Kofiridua, and SCRER.231/41). The positive impact of this policy on the environment during the period under review has depleted as a result of the over exploitation of these natural resources in contemporary times in Akyem Abuakwa.

\section{Difficulties Experienced By the Colonial Administration in Ensuring Proper Public Health}

The difficulties experienced by the colonial administration in their attempt to administer public health can be summarised as follows: inadequacy of legal provisions coupled with stiff opposition from the local authority, inadequate health workers, and lack of political support including personal issues with chiefs (PRAAD Accra, Prevention of disease in Gold, Coast, No.452/32, 1932).

\section{Inadequate Legal Provision and Stiff Opposition}

In a letter from the Chief Commissioner's Office to the governor, it highlighted the various challenges experienced by the administration in their quest to administer proper health care in the colony. The major challenge which was raised in the letter is the question on inadequate legal provisions. The Provincial Commissioner stationed at Koforidua (an area close to Akyem Abuakwa) explained that; the inadequacy of legal provision was based on the manner in which the existing ordinances were administered than to any defects in the ordinances themselves. He further reported that the bye-laws of chiefs were almost entirely ineffective and the District Commissioners of the various provinces also held this view (PRAAD Accra, Prevention of disease in Gold, Coast, No.452/32, 1932). Based on this, a suggestion was made by the Acting Deputy Director of Health. The suggestion aimed at empowering the 
government to respond quickly to places where no bye-laws existed, and in places where bye-laws existed but were not properly administered. He further recommended that the colonial provisions should be operated side by side those that existed within the native jurisdictions. In areas where there were colonial bye-laws, chiefs were not to be bordered to pass new ones (PRAAD Accra, Prevention of disease in Gold, Coast, No.452/32, 1932).

In 1903, a report by Rev. A. Ph. Bauer on Akyem Abuakwa noted among other things that "all the Akyem are unruly people. They are very obstinate and do neither obey nor respect their chiefs especially the young men" (PRAAD, Accra, Adm.11/1/1096, 1903). Similar to this, Opanyin Asare, an 82-year-old retired sanitary worker hinted that, the idea of replacing traditional bye-laws with British Ordinance marked the earliest beginning of stiff opposition from the chiefs against such rules, and an indirect opposition from the people especially in areas where chieftaincy institution was rooted like Akyem Abuakwa. The people felt that their chiefs were being disrespected by Europeans who were eager to render the native laws moribund (OPANYIN ASARE, personal conversation, $14^{\text {th }}$ February 2020).

Based on the persistent European attempts to define the legal space at the local level, chiefs felt angry; this was exacerbated by the apparent disrespect from the natives who hitherto respected them. There were several protests made by the Okyeman Traditional Council against the European interference in their native affairs, including issues of sanitation (PRAAD, Accra, Adm.11/1/1096, 1903). Therefore, restrictions placed on traditional bye laws brought stiff opposition especially from the native authority of Akyem Abuakwa. Okyeame Obeng, hinted that: people summoned and fined at the local council (traditional council) at Akyem Kukurantumi on certain barbaric customs that had negative health implications always complained during court proceedings that they could not sit in the land of their birth for a certain European to teach them what they defined as proper sanitation or how to keep their surroundings clean. The indigenes of Akyem Abuakwa believed that the traditional authorities had their own way of doing things; the indigenes of Akyem Abuakwa perceived that they were doing the right things (OKYEAME OBENG, personal conversation, $14^{\text {th }}$ February 2020).

\section{Inadequate Personnel}

Another difficulty that the colonial administration encountered in administering proper public health and sanitation was inadequate personnel. In an attempt to improve the general sanitation challenge in the Gold Coast, the Commissioner in Asante identified, among other 
Samuel ADU-GYAMFI - Phinehas ASIAMAH - Benjamin Dompreh DARKWA - Lucky TOMDI

Public Health Policies in the Akyem Abuakwa of Ghana (1850-1957)

things, limited and efficient personnel to support the sanitary force. Some of his suggestions were largely applicable to Akyem Abuakwa. A letter from the office of the Chief Commissioner in Asante to the Colonial Secretariat argued among other things that:

One of the chief obstacles to the efficient operation of the sanitary department in outlying towns and villages was that, the work was carried out to a large extent by junior African subordinates to whom the test of efficiency appeared to be the number of persecution and the adverse nature of their monthly reports (PRAAD, Accra, Prevention of Diseases in Gold Coast, No. 454/32, 1932). According to Obaapanyin Kwokwe, this was true because only few people were educated then. Therefore, having access to biomedical health workers within this period was not easy (OBAAPANYIN KWOKWE, personal conversation $14^{\text {th }}$ February 2020). Sanitary workers within this period were people with low educational background. According to Opanyin Ofori, "inadequate personnel in the government sector was as a result of high illiteracy rate among the native Gold Coasters during this period., if one completes standard 7(which is equivalent to today's Junior High School), such a person was privileged to work in a big company, it was a handful of people who had such privilege" (OPANYIN OFORI, personal conversation, $14^{\text {th }}$ February 2020).

It can be deduced that low level of education was responsible for limited personnel in the public health sector of the Colonial Administration. Therefore, the few professional public health workers were overburdened with a lot of work which had negative effect on their productivity. Obaapanyin Kwokwe hinted that; during the colonial period, the work of sanitary inspectors was tedious. They moved from community to community inspecting houses. Due to their limited number they could not expect all the places they were required to access in the performance of their duties. Obaapanyin Kwokwe further hinted that, in her village (Sokodeguaso), sanitary inspectors in Akyem Kukurantumi visited once in a blue moon. She argued that this did not put pressure on the indigenes in here village to practice proper sanitation (OBAAPANYIN KOKWE, personal conversation, $14^{\text {th }}$ February 2020). Though it was envisaged that the local people will show great concern about their environment and their own health and well-being; the activities of the sanitary officers remained paramount in ensuring proper public health in Akyem Abuakwa.

\section{Health Workers Attitude and People's Perception toward the Profession}

Health workers specifically, sanitary workers within this period were described by some as apoobofuo which literally means corrupt people. Opanyin Ofori hinted; during this period, it 
Samuel ADU-GYAMFI - Phinehas ASIAMAH - Benjamin Dompreh DARKWA - Lucky TOMDI

Public Health Policies in the Akyem Abuakwa of Ghana (1850-1957)

was their duty to inspect people's homes and especially the water they drank to ensure that their water was safe and free from bacteria. Sometimes they intentionally polluted people's water when inspecting their homes and fined them for drinking unclean water (OPANYIN OFORI, personal conversation, $14^{\text {th }}$ February 2020).

The corrupt attitude of sanitary workers was alarming hence, several people lost respect for the profession (NANCY AFUM, personal conversation, $7^{\text {th }}$ April 2020). In fact, some were of the view that, when one was employed as a sanitary inspector, the person together with his family were cursed. Lack of respect for the profession coupled with their corrupt practices impacted negatively on the sanitary progress in Akyem Abuakwa during the period. Within the period under review, some natives of Akyem Abuakwa refused to take instructions from the sanitary inspectors. Obaapanyin Esther Asare, describing the effect of these actions on the sanitary progress in Akyem Abuakwa hinted that "fines which should have been mandatorily returned to the town coffers to embark on developmental projects ended up in the pockets of the sanitary officers (tankasefos)" (OBAAPANYIN ESTHER ASARE, personal conversation, $16^{\text {th }}$ February 2020). This corrupt attitude did not aid the efforts to improve sanitation in Akyem Abuakwa which had wider ramifications on the health and wellbeing of the people.

Another huge problem experienced by the colonial administration were spiritual attacks in the form of curses. These spiritual attacks came as a result of the undesirable attitude and unprofessionalism of the sanitary workers. George Ofori noted that, corrupt practices among these workers resulted in several curses known as duabs among the Akan (OPANYIN OFORI, personal conversation, $14^{\text {th }}$ February 2020). This resulted in deaths, strange diseases and sometimes madness. Due to this, the profession was described as the cursed job. It can therefore be deduced that, one of the core reason for a small number of people in the profession was partly as a result of "spiritual attacks" (OPANYIN OFORI, personal conversation, $14^{\text {th }}$ February 2020).

\section{Conclusion}

The study has provided a historical analysis on public health policies in Akyem Abuakwa of Ghana. Adu-Gyamfi, Adjei and Owusu-Ansah have argued that, before the 1880's, the towns along the coast were notorious for their insanitary state (ADU-GYAMFI - ADJEI OWUSU-ANSAH 2013:215). Senah has argued that colonial health care prior to the 1930's was basically curative. It was rather at the beginning of the 1930's that preventive health care 
Samuel ADU-GYAMFI - Phinehas ASIAMAH - Benjamin Dompreh DARKWA - Lucky TOMDI

Public Health Policies in the Akyem Abuakwa of Ghana (1850-1957)

was introduced (SENAH 2001:84). Arhinful has argued that, the reason for the strict enforcement of preventive strategies in the 1930's was as a result of the great depression that had negative effect on public expenditure including health expenditure (ARHINFUL 2003:36). To prevent ill health among the local population, the administration resorted to preventive measures since curative health care required a lot of fiscal expenditure. The enforcement of public health policies within the colonial period was basically to improve the general health standard in the Gold Cost.

Arising from the detailed research, we argue that the implementation of these policies in Akyem Abuakwa during this period had positive impact on the health of the population at the time. Throughout the study, it was discovered that, natives in Akyem Abuakwa during the colonial period disliked European style of public health. However, the forced implementation of these policies impacted positively on the lives of the people. Public health policies in Akyem Abuakwa have undergone several transitions. Notwithstanding, choked gutters, poor location of refuse dump sites, improper disposal of refuse among others have been key challenges to public health in Akyem Abuakwa in contemporary times. This among others is a result of poor enforcement of sanitary laws and poor cooperation from the people. It is therefore pertinent for the government of Ghana and all stakeholders to pay proper attention to public health in Akyem Abuakwa. There is the need to make inferences from past public health policies to guide current action.

\section{Bibliography}

ADDAE, Stephen (1997): History of Western Medicine in Ghana. Durham: Durham Academic Press.

ADDO-FENING, Robert (1988): The Akim or Achim in the 17th Century and 18th Century Historical Context: Who Were They? In Research Review 4 (2), pp. 1-5.

ADDO-FENING, Robert (1998): The Akyem Abuakwa Asafo (1700-1918). In Transactions of the Historical Society of Ghana, New Series 2, pp. 7-19.

ADU-GYAMFI, Samuel - ADJEI, Richard (2017): Traditional Medicine. Narratives From an Indigenous Population. Port Louis: LAP LAMBERT Academic Publishing.

ADU-GYAMFI, Samuel - ADJEI, Prince Osei-Wusu - OWUSU-ANSAH, Daniel (2013): Preventive Health Care Strategies and Impact among the Asante People of the Early Twentieth Century Gold Coast: A Historical Narrative and Lessons for the Present Sanitation Challenges. In Journal of Studies in Social Science 5 (2), pp. 214-238.

DOI: 10.2478/eas-2021-0014 C) University of SS. Cyril and Methodius in Trnava. All rights reserved. 
Samuel ADU-GYAMFI - Phinehas ASIAMAH - Benjamin Dompreh DARKWA - Lucky TOMDI

Public Health Policies in the Akyem Abuakwa of Ghana (1850-1957)

ADU-GYAMFI, Samuel - BRENYA, Edward - EGYIR, Peter N. (2017): Public Health in Colonial and Post- Colonial Ghana: Lesson Drawing for the $21^{\text {st }}$ Century. In Studies in Arts in Humanities 3 (1), pp. 1-21.

ADU-GYAMFI, Samuel - DRAMANI, Aminu - AMAKYE-BOATENG, Kwasi AKOMEAH, Sampson (2017): Public Health: Socio Political History of A People. In Journal of Arts and Humanities 6 (8), pp. 11-32.

ALATINGA, Kennedy - WILLIAMS, James. J. (2014): Development Policy Planning in Ghana. The Case of Health Care Provision. In European Scientific Journal 10 (33), pp. 359-382.

AMANOR, Kojo S. (1999): Global Restructuring and Land Rights in Ghana. Forest Food Chains, Timber, and Rural Livelihoods. Research Report No. 108. Uppsala: Nordiska Afrikainstitutet.

ANDERSON, Casper - COHEN, Andrew (2016): The Government and Administration of Africa, 1880-1890. London and New York: Routledge.

ARHIN, Kwame (1985): Traditional Rules in Ghana. Past and Present. Accra: Sedco.

ARHINFUL, Kojo (2003): The Solidarity of Self-interest: Social and Economic Feasibility of Rural Health Insurance in Ghana. Leiden: Africa Studies Centre.

ASAMOAH, Samuel (2018): Historical Overview of the Development of Communal Labour from Pre-Colonial to Post Independent Ghana. In International Journal of Scientific and Research Publication 8 (4), pp. 10-16.

BERRIDGE, Virginia (2016): Public Health: A Very Short Introduction. Oxford: Oxford University Press.

BHATTACHARYYA, Jnanabrata. (2004): Theorizing Community Development. In Community Development 34 (2), pp. 5-34.

BOSTON UNIVERSITY (2015): A Brief History of Public Health": Office of teaching and Digital Learning. Available at https//www.Sphweb.bumc.bu.edu/otlt/MPH-Modules/ $\mathrm{Ph} /$ PublicHealthHistory-print.html.

CENTER FOR DISEASE CONTROL AND PREVENTION. (2018): Available at https://www.cdc.gov/publichealth101/public-health.html.

FERSHTMAN, Chaim - GNEEZY, Uri - HOFFMAN, Moshe (2011): Taboos and Identity. Considering the Unthinkable. In American Economic Journal: Microeconomics 3 (2), pp. 139-164.

GOCKING, Roger S. (2005): The History of Ghana. Santa Barbara: Greenwood Press. 
Samuel ADU-GYAMFI - Phinehas ASIAMAH - Benjamin Dompreh DARKWA - Lucky TOMDI

Public Health Policies in the Akyem Abuakwa of Ghana (1850-1957)

GRAY, Natasha Adriene (2000): The Legal History of Witchcraft in Colonial Ghana: Akyem Abuakwa, 1913-1943. New York: Columbia University.

GRISSOM, Julie Hayden (2004): Explaining Plague in Early Modern Europe: The Role of Contagion in the Theories of Girolamo Fracastoro and Thomas Willis. MA Thesis. Norman: The University of Oklahoma.

HEBBERT, Michael (1999): A City in Good Shape. Town Planning and Public Health. In The Town Planning Review 70 (4), pp. 433-453.

JANZEN, John M. - GREEN, Edward C. (2017): Medicine in Africa. In Journal of African Studies, pp. 1-18.

KITULA, A. G. N. (2006): The Environmental and Socio-Economic Impacts of Mining on Local Livelihoods in Tanzania. A Case Study of Geita District. In Journal of Cleaner Production 14 (3-4), pp. 405-414.

KNOLL, Arthur J. (1967): Taxation in the Gold Coast Colony and in Togo: A Study in Early Administration. In Gifford Prosser, Roger Louis (eds.): Britain and Germany in Africa. Imperial Rivalry and Colonial Rule. New Haven: Yale University Press, pp 417 453.

KOSOE, Enoch A. - DIAWUO DARKO, Francis - OSUMANU, Issaka Kanton (2019): Looking into the Past: Rethinking Traditional Ways of Solid Waste Management in the Jaman South Municipality, Ghana. In Ghana Journal of Geography 11 (1), pp. 228-244.

NKWAM, Ejogha Florence (1988): British Medical and Policies in West Africa, 19201960. A Thesis Submitted for the Degree of Doctor of Philosophy in the University of London School of Oriental and African Studies. London: University of London School of Oriental and African Studies.

NYARKO, John (2018): History of The Abuakwas of Akyem, Ghana. Accessible on: https://www.researchgate.net/publication/325049235_HISTORY_OF_THE_ABUAKWA S_OF_AKYEM_GHANA.

OFOSU-AMAAH, Samuel (2005): Health and Disease in Ghana: The Origins of Disease and the Future of Our Health. Accra: Ghana Academy of Arts and Sciences.

OFOSU-MENSAH, Emmanuel Ababio (2017): Historical and Modern Artisanal SmallScale Mining In Akyem Abuakwa, Ghana. In Africa Today 64 (2), pp. 69-91.

OZIOMA, Ezekwesili-Ofili J. - CHINWE, Okaka A. N. (2019): Herbal Medicines in African Traditional Medicine. In Herbal Medicine 10, pp. 191-214.

PATTERSON, David K. (1981): Health in Colonial Ghana. Disease, Medicine, and Socio-Economic Change, 1900-1955. Waltham: Crossroads Press. 
Samuel ADU-GYAMFI - Phinehas ASIAMAH - Benjamin Dompreh DARKWA - Lucky TOMDI

Public Health Policies in the Akyem Abuakwa of Ghana (1850-1957)

SENAH, Kodjo A. (2001): In Sickness and in Health. Globalization and Health Care Delivery in Ghana. In Institute of African Studies Research Review 17 (1), pp. 83-89.

STROTHER, Christian (2016): Waging War on Mosquitoes: Scientific Research and the Formation of Mosquito Brigades in French West Africa, 1899-1920. In Journal of the History of Medicine and Allied Sciences 71 (4), pp. 447-468.

THORNDIKE, Lynn (1928): Sanitation, Baths, and Street-Clearing in the Middle Ages and Renaissance. Speculum 3 (2), pp. 192-203.

TOUNTAS, Yannis (2009): The Historical Origins of the Basic Concepts of Health Promotion and Education. The Role of Ancient Greek Philosophy and Medicine. In Health Promotion International 24 (2), pp. 185-192.

TULCHINSKY, Theodore H. - VARAVIKOVA, Elena A. (2014): The New Public Health. London: Elsevier Academic Press.

TWUMASI, Patrick A. (1975): Medical Systems in Ghana. A Study in Medical Sociology. Accra: Ghana Publishing Corporation.

WILLIAMS, Cicely D. (1938): Child Health in the Gold Coast. In Child Health in the Gold Coast, pp. 97-102.

WORLD LIFE FUND (2020). We Need To Protect Our Forest. Available at https://wwf.panda.org/our_work/our_focus/forests_practice/importance_forests/.

\section{Interviews}

MADAM NANCY AFUM, personal communication, $7^{\text {th }}$ April 2020.

OBAAPANYIN ADWOA KWOKWE, $14^{\text {th }}$ February 2020.

OBAAPANYIN ESTHER ASARE, personal communication, $10^{\text {th }}$ February 2020.

OKYEAME OBENG, personal communication, 16 $6^{\text {th }}$ April 2020.

OPANYINGEORGE OFORI, personal communication, 14 ${ }^{\text {th }}$ February 2020.

MR. EMMANUEL ASIHE, personal communication, 16 $6^{\text {th }}$ February 2020.

OBAAPANYIN AMA WUKUBEA, personal communication, March $6^{\text {th }} 2020$.

\section{Archival Materials}

PRAAD, Accra, “Cap 86 Towns Act, 1892”, Arrangement of Sections. 
Samuel ADU-GYAMFI - Phinehas ASIAMAH - Benjamin Dompreh DARKWA - Lucky TOMDI

Public Health Policies in the Akyem Abuakwa of Ghana (1850-1957)

PRAAD, Accra, C.S.O/14/172, "Health Boards" File No. 293/32.

PRAAD, Accra, C.S.O/833/33, "Kyebi Sanitation: The Sanitary Conditions of Kyebi", 1933.

PRAAD, Accra, Colonial Secretary Office, "Constitution of A Central Health Board", M.P No. $1301 / 1926$.

PRAAD, Accra, AMD, 4/1/55, "The Town Amendment Ordinance of 1926".

PRAAD, Accra, NAG. Adm.11/1/1096, A ph. Bauer to Col. 29 th January 1903.

PRAAD, Accra, The Infectious Diseases Act, 1908, Cap 78. 24 th April 1908.

PRAAD, Koforidua, "The New Juabeng Native Authority, Slaughter House Rules, 1948". (Under Section 20 the Ordinance).

PRAAD, Koforidua, Complication of Customary law" Akyem Abuakwa Traditional Council Ref. No. A.20/SF4/74 of August 1975.

PRAAD, Accra, C.S.O 11/14/205, "Public Slaughter House Kyebi” File No. 558/31, 1934.

PRAAD, Accra, A Letter from the Chief Commissioner Office- Ashanti to the Colonial Secretariat, dated 24 $4^{\text {th }}$ September 1932 file No.454/32.

PRAAD, Accra, ADM4/1/56, Mining Health Areas Ordinance.

PRAAD, Accra, Office of the Provincial Commissioner, "Prevention of Disease in the Gold Coast; Difficulties Arising In Connection With. File No. 454/32.

PRAAD, Koforidua, "Forest Ordinance" File No SCRER.231/41. 
Samuel ADU-GYAMFI - Phinehas ASIAMAH - Benjamin Dompreh DARKWA - Lucky TOMDI

Public Health Policies in the Akyem Abuakwa of Ghana (1850-1957)

Samuel ADU-GYAMFI is a Senior Lecturer at the Department of History and Political Studies of the Kwame Nkrumah University of Science and Technology, Kumasi-Ghana. He is the Senior Editor of Cogent Arts and Humanities Journal (History). His research focus is in Applied History, Asante History, Medicine, Culture, History Education, Health Policy, Social Policy, Social Medicine, Societal Studies and Social Change. Through Applied History, he makes explicit attempt to illuminate current challenges and choices by analysing historical precedents and analogues. He begins with a current choice or predicament and provides a perspective from history, responding to the history deficit in policy. ORCID: 0000-0002-0193-867X

Phinehas ASAMIAH is a Teaching and Research Assistant at the Department of History and Political Studies of the Kwame Nkrumah University of Science and Technology, Kumasi-Ghana. His research focusses on the History of Medicine and Public Health.

Benjamin Dompreh DARKWA is a historian and is currently an MPhil History candidate at the Department of History and Political Studies of the Kwame Nkrumah University of Science and Technology, Kumasi-Ghana. Benjamin primarily focuses his research on the History of Medicine, Environment and Culture. His interest is linked to how the discourses of Medicine, Health and Culture have been shaped throughout History. ORCID: 0000-0003-16629789

Lucky TOMDI is a Master of Arts Candidate at the Department of History, University of New Brunswick in Fredericton, Canada. His research lies in the History of Health, Medicine and African Diaspora with particular focus on health systems. He applies historical methodologies to analyse contemporary health system challenges at the heart of policy making. ORCID: 0000-00020463-5797 